\title{
ANALISIS USER INTERFACE TERHADAP WEBSITE AKTA ONLINE BANYUWANGI MENGGUNAKAN METODE HEURISTIC EVALUATION
}

\author{
Siti Vika Ngainul F*, Oktalia Juwita**, Tio Dharmawan *** \\ *Fakultas Ilmu Komputer, Universitas Jember \\ **Fakultas Ilmu Komputer, Universitas Jember \\ *** Fakultas Ilmu Komputer, Universitas Jember \\ *vika.ngainul16@gmail.com**oktalia@unej.ac.id***tio.pssi@unej.ac.id
}

\begin{abstract}
Banyuwangi Regency has a new innovation called "Lahir Procot Pulang Bawa Akta " which in this innovation is realized in the form of an Online Deed Website. Every information technology has an interface that can be a link between the user and the technology itself. Interface formation is influenced by needs, and information technology has different interface designs according to the needs of its users. The User Interface has the aim of making it easier for users to operate information technology that can make users feel comfortable using the application or technology. Heuristic Evaluation is one of the Usability evaluation methods that can be used to determine the extent to which a system is used by users to achieve certain goals with effectiveness, efficiency and satisfaction. This research is a research that is focused on the use of Heuristic Evaluation based on user interface design aspects of application usability through observation, interviews and questionnaires to users.
\end{abstract}

Keyword: User Interface, Heuristic Evaluation, Website Akta Online Banyuwangi.

\section{Pendahuluan}

Perkembangan Teknologi Informasi salah satunya adalah website. Website merupakan gambaran diri dari internet dapat diibaratkan website sebagai sebuah tempat di intern [1]. Kabupaten Banyuwangi mempunyai inovasi baru yaitu "Lahir Procot Pulang Bawa Akta" dimana pada inovasi ini diwujudkan dalam bentuk Website Akta Online.

Setiap teknologi informasi mempunyai interface yang dapat menjadi penghubung antara pengguna dan teknologi itu sendiri. Pembentukan interface dipengaruhi oleh kebutuhan, dan teknologi informasi mempunyai desain interface yang berbeda-beda sesuai dengan kebutuhan penggunanya [2]. Heuristic Evaluation merupakan salah satu metode evaluasi Usability yang dapat digunakan untuk mengetahui sejauh mana sebuah sistem digunakan oleh pengguna untuk mencapai tujuan tertentu dengan efektifitas, efisiensi dan kepuasan [3].

Untuk dapat mengetahui kegunaan, efisiensi, dan efektifitas dari interface terhadap teknologi yang digunakan pada Website Akta Online Banyuwangi, maka perlu dilakukan evaluasi. Evaluasi menggunakan Heuristic Evaluation bertujuan untuk dapat mengetahui kegunaan efisiensi, dan efektifitas dari interface yang berbasis pada sepuluh prinsip Jacob Nielsen yaitu Visibility of system status, match with the real wolrd, user control and freedom, consistency and standard, error prevention, recognition than recall, flexibility and efficiency of use, aesthetic and minimalist design, help users recognize diagnose, and recover from errors, dan Help and documentation [4]. 


\section{Metode Penelitian}

\subsection{Sampel Penelitian}

Sampel pada penelitian ini ditentukan dengan menggunakan metode purposive sampling. Purposive sampling merupakan salah satu metode nonprobability sampling yang unsur-unsurnya ditentukan dari target populasi berdasarkan kecocokannya dengan tujuan penelitian serta kriteria inklusi dan eksklusi tertentu [5]

\subsection{Tahapan Penelitian}

Alur penelitian merupakan urutan langkah penelitian yang dilakukan mulai dari identifikasi masalah, studi literatur, pengembangan dan penyusunan instrumen, pengumpulan data, analisis data, dan penyusunan hasil rekomendasi. Diagram alur dapat dilihat pada Gambar 3.1.

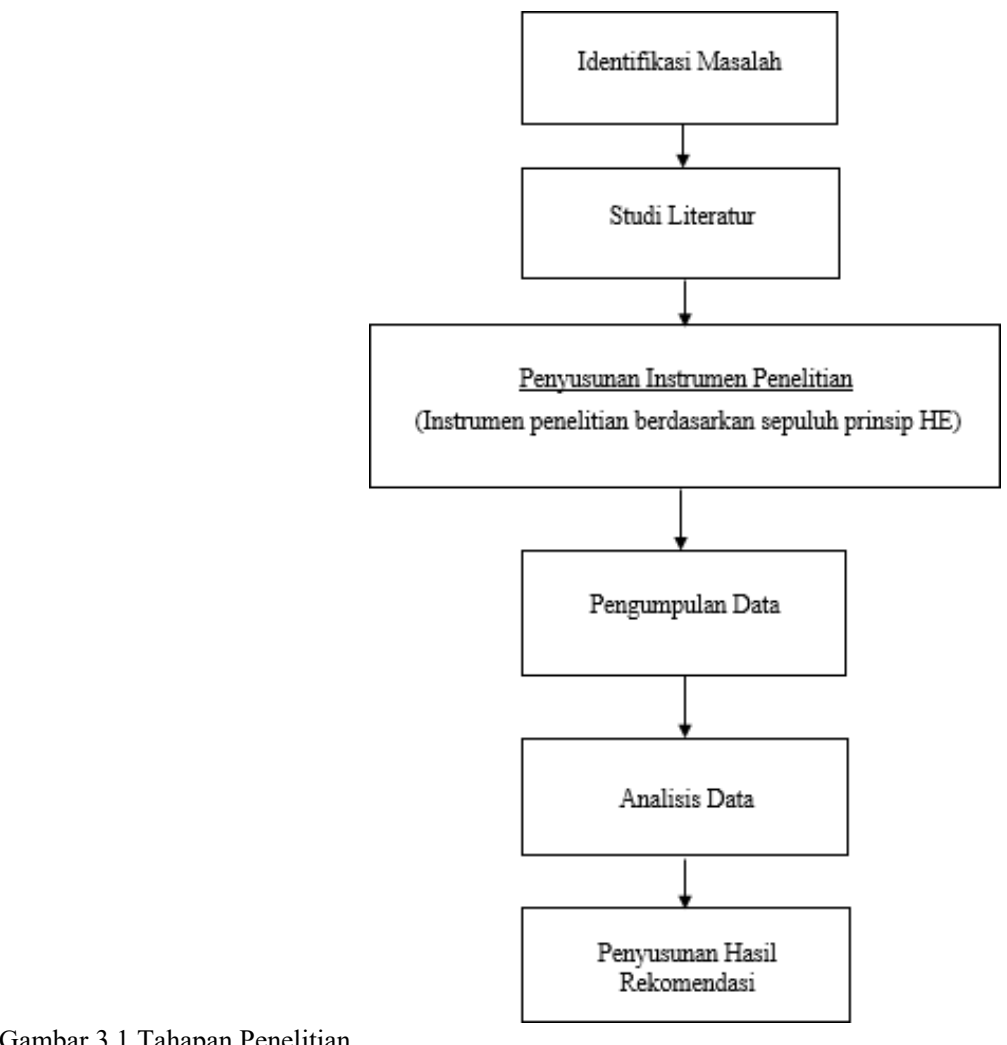

\subsection{Identifikasi Masalah}

Identifikasi masalah adalah proses menentukan topik penelitian dan alasan mengapa topik yang ditentukan perlu diteliti. Tahapan identifikasi masalah dilakukan untuk mendapatkan informasi mengenai pembahasan penelitian terdahulu tentang Heuristic Evalustion.

\subsection{Studi Literatur}

Studi literatur adalah teknik pengumpulan data dengan melakukan penelaahan terhadap berbagai buku, literatur, catatan, serta berbagai laporan yang berkaitan dengan penelitian [6]. Disini, penulis menggunakan beberapa referensi untuk mendukung penelitian yang dilakukan.

\subsection{Penyusunan Instrumen}

Penyusunan instrumen penelitian ini berdasarkan sepuluh prinsip Jacob Nielsen pada Heuristic Evaluation. Instrumen penelitian ini merupakan pertanyaan yang disusun dalam bentuk kuesioner

\subsection{Pengumpulan Data}

Metode pengumpulan data dilakukan untuk mendapatkan data yang dibutuhkan selama penelitian ini dilakukan. Pengumpulan data yang dilakukan peneliti menggunakan metode observasi, wawancara dan kuisioner. Data kuesioner didapat dari beberapa Rumah Sakit di Kabupaten Banyuwangi. 


\subsection{Analisis Data}

Analisis data pada penelitian ini meggunakan metode Heuristic Evaluation dengan menggunakan 10 variabel HE. Analisis dilakukan berdasarkan jawaban dari hasil wawancara dan juga nilai prioritas masalah yang ada (saverity ratings). Severity ratings digunakan untuk menentukan prioritas masalah yang ditemukan pengguna, dari tingkat prioritas masalah yang ditemukan akan berpengaruh seberapa penting perlu adanya perbaikan. Hasil severity ratings tersebut yang akan dijadikan untuk menentukan rekomendasi perbaikan.

\section{Hasil dan Pembahasan}

\subsection{Hasil Analisis}

1. Visibility Of System Status

Sistem harus dapat memberikan informasi kepada pengguna tentang apa yang sedang terjadi dengan jelas kepada pengguna. Pada kasus ini yaitu Visibility System Of Status terdapat dua pertanyaan yang tidak ada masalah dan nyaman untuk digunakan dengan nilai saverity ratings yaitu 0 atau Don't Agree. Satu pertanyaan dengan masalah pada adanya fitur beranda tetapi hanya tampilan kosong. Dengan permasalahan seperti itu maka nilai severity ratings 1 atau Cosmetic Problem.

2. $\quad$ Match Between System and The Real World

Sistem harus menggunakan kata dan kalimat yang biasa digunakan oleh pengguna. Pada kasus ini yaitu Match Between System and The Real World website akta online bisa dikatakan sudah baik dengan kedua pertanyaan menyatakan tidak ada masalah karena pengguna merasa bahasa dan icon lainnya mudah untuk dimengerti oleh pengguna jadi pada item ini tidak ada masalah dan nyaman untuk digunakan dengan nilai severity ratings 0 atau Don't Agree.

3. User Control and Freedom

Pengguna mempunyai kebebasan untuk memilih dan melakukan pekerjaan sesuai dengan kebutuhan ketika sedang menjalankan sistem. Pada kasus ini yaitu User Control And Freedom website akta online bisa dikatakan sudah baik dengan ketiga pertanyaan menyatakan tidak ada masalah, karena pengguna dengan mudah mencari nama pemohon dengan menuliskan nama pada kolom pencarian yang terletak diatas daftar nama pemohon akta. Jadi pada item ini tidak ada masalah dan nyaman untuk digunakan dengan nilai severity ratings 0 atau Don't Agree.

4. Consistency and Standards

Standar yang digunakan pada sistem harus konsisten dalam hal penulisan sebuah kata, jenis huruf sehingga pengguna tidak bingung dengan situasi yang terjadi. Pada kasus ini yaitu Consistency and Standards website akta online bisa dikatakan sudah baik dengan ketiga pertanyaan menyatakan tidak ada masalah. Jadi pada item ini tidak ada masalah dan nyaman untuk digunakan dengan nilai severity ratings 0 atau Don't Agree.

5. Error Prevention

Merancang sebuah sistem untuk mencegah dan meminimalisir adanya kesalahan pada pengguna. Pada kasus ini yaitu Error Prevention terdapat satu pertanyaan yang tidak ada masalah dan nyaman untuk digunakan dengan nilai saverity ratings yaitu 0 atau Don't Agree. Kemudian satu pertanyaan dengan masalah pada tombol reset Karena ketika terjadi error atau tidak dapat berfungsi saat menginputkan data, tidak terdapat pemberitahuan sehingga menyebabkan pengguna kebingungan. Maka severity ratings bernilai 2 atau Minor Usability Problem karena pada kasus ini beberapa pengguna mengalami kesulitan pada saat menjalankan aktifitasnya.

6. Recognition rather than retail

Sistem membantu pengguna dalam mengenali, mendiagnosa, dan mengatasi masalah. Pada kasus ini yaitu Recognition rather than Recall website akta online bisa dikatakan sudah baik dengan kedua pertanyaan menyatakan tidak ada masalah karena pengguna merasa langkah-langkah yang ada pada website sudah jelas dan mudah dijalankan. Jadi pada item ini tidak ada masalah dan nyaman untuk digunakan dengan nilai severity ratings 0 atau Don't Agree.

7. Flexibility and efficiency of use

Sistem memberikan kemudahan bagi pengguna baru dan yang sudah berpengalaman untuk nyaman dalam mengakses sistem. Pada kasus ini yaitu Recognition rather than Recall website akta online bisa dikatakan sudah baik dengan kedua pertanyaan menyatakan tidak ada masalah. Jadi pada item ini tidak ada masalah dan nyaman untuk digunakan dengan nilai severity ratings 0 atau Don't Agree. 
8. $\quad$ Aesthetic and minimalist design

Sistem dapat memberikan informasi yang relevan serta tampilan yang sesuai dengan kebutuhan sistem, informasi yang tidak relevan mengurangi visibilitas dan usability dari sistem. Pada kasus ini yaitu Aesthetic and Minimalist Design website akta online bisa dikatakan sudah baik dengan ketiga pertanyaan menyatakan tidak ada masalah. Jadi pada item ini tidak ada masalah dan nyaman untuk digunakan dengan nilai severity ratings 0 atau Don't Agree.

9. Help users recognize, diagnose and recovers from errors

Sistem dapat menyampaikan pesan kesalahan yang terjadi dengan jelas, agar mudah di mengerti oleh pengguna. Pada kasus ini yaitu Help Users Recognize, Dialogue, and Recovers From Errors terdapat masalah pada saat pengguna klik tombol login, pengguna tidak dapat masuk ke menu berikutnya melainkan harus memasukkan username dan password yang sama dan login dua kali. Dari permasalahan tersebut sangat tidak efektif jika dilakukan. Dengan permasalahan seperti itu maka nilai severity ratings 2 Minor Usability Problem.

10. Help and documentation

Sistem harus memiliki dokumentasi yang relevan dan fitur help yang baik, sehingga dapat membantu pengguna pada saat menggunakan sistem. Pada kasus ini yaitu Help and Documentation terdapat masalah yaitu tidak terdapat menu bantuan sehingga pengguna merasa kesulitan ketika mengalami kesalahan. Dengan permasalahan seperti itu maka nilai severity ratings 3 atau Major Usability Problem

\subsection{Rekomendasi}

\begin{tabular}{lll}
\hline No & Prinsip Heuristic Evaluation & \multicolumn{1}{c}{ Rekomendasi } \\
\hline 1 & Error prevention & $\begin{array}{l}\text { Perlu adanya penambahan popup dialog box ketika terjadi error saat } \\
\text { menggunakan tombol dan tombol reset diganti namanya dengan } \\
\text { tombol submit. }\end{array}$ \\
\hline $\begin{array}{l}\text { Help users recognize, } \\
\text { dialogue, and recovers from } \\
\text { errors }\end{array}$ & $\begin{array}{l}\text { Perlu adanya tambahan menu pada tampilan home yaitu kontak } \\
\text { informasi yang berisikan nomer telepon dan link email. } \\
\text { Perlu adanya menu tambahan seperti pesan yang berisikan notifikasi } \\
\text { yelp and documentation }\end{array}$ & \begin{tabular}{l} 
Perlu adanya tambahan menu help and ask. \\
\hline 3
\end{tabular}
\end{tabular}

\section{Kesimpulan}

Pada penelitian ini evaluasi dilakukan menggunakan metode Heuristic Evaluation dengan Severity Ratings yang digunakan untuk menentukan perbaikan sebuah sistem sesuai dengan prioritas masalah yang ditemukan. Dari hasil penerapan metode Heuristic Evaluation dengan 10 prinsip yang telah digunakan dalam penelitian ini, maka terdapat 7 prinsip Heuristic Evaluation yang tidak ditemukan masalah usability dan tidak memerlukan perbaikan yaitu pada prinsip Visibility Of System Status, Match Between System and The Real World, User Control and Freedom, Consistency and Standards, Recognition Rather Than Recall, Flexibility and Efficiency Of Use, Aesthetic and Minimalist Design. Kemudian 3 prinsip yang ditemukan masalah usability dan menghasilkan rekomendasi perbaikan yaitu pada prinsip Error Prevention, Help User Recognize Dialogue and Recovers From Errors, dan Help and Documentation.

\section{Daftar Pustaka}

[1] Nugraheny, Dwi. 2016. "Analisis User Interface dan User Experience Pada Website Sekolah Tinggi Teknologi Adisutjipto Yogyakarta". SENATIK. 2528-1666

[2] Nurlifa, Alfian. Sri Kusumadewi \& Kariyam. 2014. “Analisis Pengaruh User Interface Terhadap Kemudahan Penggunaan Sistem Pendukung Keputusan Seorang Dokter". Yogyakarta

[3] Anggitama, Dhika Rozqi., Herman Tolle., \& Hanifah Muslimah Az- Zahra. 2018. Evaluasi Dan Perancangan User Interface Untuk Meningkatkan User Experience Menggunakan Metode Human Centered Design Dan Heuristic Evaluation Pada Aplikasi EzyPay. Jurnal Pengembangan Teknologi Informasi dan Ilmu Komputer 2(12)

[4] Sulistiyono, M. 2017. "Evaluasi Heuristic Sistem Informasi Pelaporan Kerusakan Laboratorium Universitas AMIKOM Yogyakarta”. Jurnal IImiah DASI, 37-43. 
[5] Daniel, J. (2012). Sampling Essentials: Practical Guidlines for Making Sampling Choices. United States: SAGE Publications.

[6] Nazir. (1998). Metode Penelitian. Jakarta : Rineka Cipta 